\title{
Acute ackee fruit intoxication
}

INSERM

\section{Source}

INSERM. (1999). Orphanet: an online rare disease and orphan drug data base. Acute ackee fruit intoxication. ORPHA:73423

Acute ackee fruit intoxication (also referred to as Jamaican vomiting syndrome or sickness) is caused by the ing estion of unripe Blighia sapida fruits. It is a serious intoxication that is frequent in certain countries in the Caribbean and Western Africa. In contrast, it is rare in France and other Western countries. Intoxication leads to toxic hypoglycaemia and inhibition of neog lucogenesis. The hypoglycaemia is caused by the effect of hypoglycin A, which is found in the arils. 